\title{
Sistem Monitoring Kehadiran Perkuliahan Berbasis Face Detection Menggunakan Algoritma Viola Jones
}

\author{
Zulfachmi ${ }^{1}$, Made Sudarma ${ }^{2}$, Lie Jasa ${ }^{3}$ \\ [Submission: 07-02-2019, Accepted: 15-04-2019]
}

\begin{abstract}
Presence of lectures is an important factors to take the final exam. It is necessary to have a presence system with computer vision technology that is capable to handling problems manually. Common problems are duplicate signatures, incorrect class schedules, and lecture reports. In this research, computer vision technology used is facial recognition. The stages of face recognition in this study are detection, feature extraction and recognition. The methods support face recognition process are Viola-Jones, Sobel, and KNN methods. Viola-Jones method in this study is applied to the face detection process, where the accuracy is more than $90 \%$. While the process of feature extraction using Sobel method. And face recognition process using KNN method, wherein the method KNN has a high accuracy rate. Additionally in this study using distance determination facial image acquisition and position of the face. The accuracy of this study was $94.79 \%$.
\end{abstract}

Key Words- Computer Vision, Face Detection, List of Attendance, Viola-Jones Algorithm .

Intisari- Daftar kehadiran perkuliahan adalah salah satu faktor penting pada aktivitas perkuliahan karena merupakan salah satu syarat untuk mengikuti ujian akhir semester. Mengingat pentingnya kehadiran perkuliahan maka diperlukan sistem kehadiran dengan teknologi komputer vision yang diharapkan mampu mengatasi permasalahan pada presensi secara manual. Permasalahan-permasalahan umum yang terjadi pada presensi secara manual yaitu duplikasi tanda tangan, salah mengikuti jadwal kuliah, dan pembuatan laporan perkuliahan. Pada penelitian ini teknologi komputer vision yang digunakan ialah pengenalan wajah. Adapun tahap-tahap pengenalan wajah pada penelitian ini yaitu pendeteksian, ekstraksi ciri dan pengenalan. Metode-metode yang mendukung proses pengenalan wajah yaitu metode Viola-Jones, Sobel, dan KNN. Metode ViolaJones pada penelitian ini diterapkan pada proses pendeteksian wajah, dimana tingkat akurasi dari metode Viola-Jones lebih dari $90 \%$. Sedangkan proses ekstraksi ciri menggunakan metode sobel. Dan proses pengenalan wajah menggunakan metode KNN, dimana metode KNN memiliki tingkat akurasi yang tinggi. Selain itu pada penelitian ini menggunakan penentuan jarak pengambilan citra wajah dan posisi wajah. Tingkat keakurasian dari penelitian ini adalah sebesar $94.79 \%$.

Kata Kunci- Algoritma Viola-Jones, Daftar Kehadiran Perkuliahan, Komputer Vision, Pendeteksian Wajah.

\footnotetext{
${ }^{1}$ Mahasiswa Pascasarjana, Teknik Elektro Fakultas Teknik Universitas Udayana, Jln. Kampus Bukit Jimbaran 80361 INDONESIA (telp: 0361-703315; fax: 0361-4321; e-mail fahmi.alfahim.93@gmail.com)

2, 3 Dosen, Jurusan Teknik Elektro Fakultas Teknik Universitas Udayana, Jln. Kampus Bukit Jimbaran 80361 INDONESIA (telp: 0361-703315; fax: 0361-4321; e-mail: imasudarma@gmail.com,liejasa@unud.ac.id)
}

\section{PENDAHULUAN}

Daftar kehadiran perkuliahan atau biasa disebut dengan presensi merupakan salah satu kegiatan yang rutinitas yang dilakukan oleh mahasiswa sebelum perkuliahan dilaksanakan untuk membuktikan bahwa dirinya hadir diperkuliahan. Daftar hadir perkuliahan adalah salah satu faktor penting pada aktivitas perkuliahan karena merupakan syarat untuk mengikuti ujian akhir semester dan pertimbangan dosen untuk menentukan nilai bagi mahasiswa. Dengan faktor-faktor tersebut maka daftar hadir perkuliahan menjadi acuan apakah mahasiswa tersebut layak untuk mengikuti ujian akhir semester dan mendapatkan nilai yang bagus. Pada pelaksanaan pengecekan daftar kehadiran yang secara manual diperlukan suatu ketelitian khusus agar tidak terjadi kesalahan dalam menilai kehadiran dari masing-masing mahasiswa. Oleh karena itu, sistem kehadiran perkuliahan perlu dikembangkan dengan sistem yang sudah terkomputerisasi yang mendasar pada penggunaan password, barcode, dan teknologi pengenalan wajah.

Adapun sistem kehadiran yang telah diteliti oleh peneliti sebelumnya yaitu presensi menggunakan sidik jari [1] ataupun RFID card [2]. Berdasarkan penelitian tersebut sistem kehadiran menggunakan sidik jari dan RFID card masih sangat rentan untuk diduplikasi [3]. Untuk meminimalkan kecurangan tersebut, maka diperlukan sebuah sistem pengenalan wajah yang terkomputerisasi untuk mengatasi permasalahan saat melakukan kehadiran perkuliahan dan manipulasi data kehadiran.

Dari permasalahan tersebut, maka diperlukan suatu unsur keunikan fisik setiap manusia yaitu salah satunya pengenalan wajah. Melalui sistem pengenalan wajah ini ciri-ciri dan keunikan fisik manusia dapat dijadikan sebagai identifikasi, otentikasi dan keamanan [4]. Deteksi wajah adalah salah satu proses penting di dalam sistem pengenalan wajah. Sistem Pengenalan wajah telah banyak diaplikasikan pada sistem keamanan selain pengenalan iris mata dan pengenalan sidik jari. Selain itu deteksi wajah juga dapat digunakan untuk pencarian dan pengindeksian citra atau video yang di dalamnya terdapat wajah manusia dalam berbagai bentuk, ukuran, posisi, dan warna kulit [5]. Seiring perkembangan teknologi, sistem pengenalan wajah semakin banyak dimanfaatkan dalam segala hal baik pada sistem kehadiran, sistem keamanan, dan maupun pada perangkat lunak lainnya. Dengan sistem pengenalan wajah, identitas diri seseorang akan mudah diketahui dengan bantuan kamera yang telah dihubungkan ke sistem terkomputerisasi. Penggunaan sistem pengenalan wajah memiliki keunggulan dibandingkan dengan sistem tradisional seperti penggunaan password, PIN, kartu 
dan kunci yang sudah diterapkan pada akses pintu, presensi kehadiran, dll.

Adapun metode-metode pengenalan wajah yang dapat mendukung sistem kehadiran perkuliahan berbasis pengenalan wajah, yaitu Principal Component Analysis (PCA), Convolutional Neural Networks (CNN), Eigen Face, dan $K$ Nearest Neighbor. Dari beberapa penelitian yang sudah dilakukan yaitu pengenalan wajah menggunakan metode Principal Component Analysis (PCA) yang menghasilkan akurasi sebesar $80 \%$ [6], dan sistem kehadiran perkuliahan menggunakan ekstraksi fitur Principal Component Analysis (PCA) yang membahas sistem presensi menggunakan identifikasi wajah yang dikembangkan dengan menggunakan handphone berbasis android dengan akurasi sebesar 90\% [7], kemudian penelitian dengan menggunakan metode Convolutional Neural Networks (CNN) pada pengenalan wajah secara real-time menghasilkan akurasi sebesar 87\% [8]. Selain itu terdapat juga penelitian sistem kehadiran menggunakan Eigen Face Recognition (Rekha \& Ramaprasad, 2017). Berdasarkan beberapa metode yang telah diuraikan diatas, terdapat sebuah metode dengan akusisi citra atau pendeteksian wajah, preprocessing, ekstraksi fitur dan klasifikasi citra wajah dengan menghasilkan akurasi sebesar 98.33\% (Fandiansyah, 2017), dengan demikian sistem kehadiran perkuliahan berbasis pengenalan wajah dapat diterapkan dengan metode tersebut.

Dari beberapa penelitian sebelumnya, terdapat metode Viola-Jones yang merupakan metode pendeteksian obyek dengan tingkat keakuratan yang cukup tinggi dan kemampuan detektor metode ini lebih cepat dibandingkan dengan detektor Rowley Baluja-Kanade dan detektor Schneiderman-Kanade dimana tingkat keakuratannya sebesar 93,7\% [11], terdapat juga penelitian pengenalan wajah secara realtime dengan algortima Viola-Jones sebagai detektor dan metode eigenface sebagai pengenalan wajah dengan hasil akurasi sebesar $90 \%$ [12]. Dengan demikian algoritma Viola-Jones tentunya akan cocok untuk diimpelementasikan pada proses pendeteksian wajah di sistem kehadiran perkuliahan berbasis pengenalan wajah karena memiliki tingkat akurasi yang tinggi.

Secara umum proses ekstraksi fitur yang sering digunakan untuk mendeteksi suatu objek ialah deteksi tepi objek. Pada deteksi tepi objek terdapat beberapa metode yang dapat digunakan yaitu metode gradien, metode canny, metode prewitt, dan metode sobel. Berdasarkan penelitian sebelumnya deteksi tepi menggunakan metode sobel lebih tajam dalam kualitas citra dibandingkan dari beberapa metode deteksi tepi lainnya [13]. Setelah melalui proses ektraksi fitur, suatu objek akan diklasifikasikan berdasarkan identitas ataupun ciri-ciri dari suatu objek tersebut. Adapun beberapa metode yang mendukung klasifikasi suatu objek seperti fuzzy logic, support vector machine, naive bayes, dan $k$ nearest neighbor. Dari beberapa penelitian yang telah dilakukan metode klasifikasi dengan menggunakan $k$ nearest neighbor memiliki akurasi yang cukup tinggi yaitu sebesar 91,25\% [14]. Oleh karena itu, metode $k$ nearest neighbor dapat diterapkan pada proses klasifikasi sistem pengenalan wajah.

Selain itu pada penelitian yang telah diuraikan diatas belum adanya kombinasi antara presensi yang dilakukan dengan jadwal perkuliahan dan serta mata kuliah yang diambil oleh mahasiswa. Oleh karena hal itu, pada penelitian ini penulis akan mengimplementasikan sistem kehadiran perkuliahan yang terintegrasi dengan matakuliah yang diambil dan jadwal perkuliahan. Sistem yang dirancang akan mampu mengatasi permasalahan bagi mahasiswa yang kuliah tidak sesuai dengan mata kuliah yang diambilnya, mengatasi mahasiswa yang tidak mengetahui jadwal perkuliahannya, dan mengatasi masalah yang tidak mengetahui ruangan kelas perkuliahan. Sistem kehadiran perkuliahan ini juga mampu mengatasi masalah utama pada bagian akademik dalam pembuataan laporan presensi tiap bulan maupun laporan kehadiran perkuliahan pada akhir semester.

Berdasarkan uraian latar belakang di atas, maka penulis tertarik untuk melakukan penelitian di bidang sistem kehadiran perkuliahan dan pengolahan citra wajah. Sistem Monitoring Kehadiran Perkuliahan Menggunakan Face Detection dengan Algoritma Viola-Jones diharapkan mampu mengatasi permasalahan-permasalahan mahasiswa pada kehadiran perkuliahan dan memudahkan pekerjaan bagi divisi akademik dalam kesehariannya.

\section{Metodologi Penelitian}

\section{A. Algoritma Viola-Jones}

Pada tahapan ini mengimplementasikan algoritma ViolaJones pada sistem monitoring kehadiran perkuliahan yang dibangun untuk mendeteksi wajah mahasiswa ketika melakukan pengambilan dataset. Flowchart dari algoritma viola jones dapat dilihat pada Gambar 1.

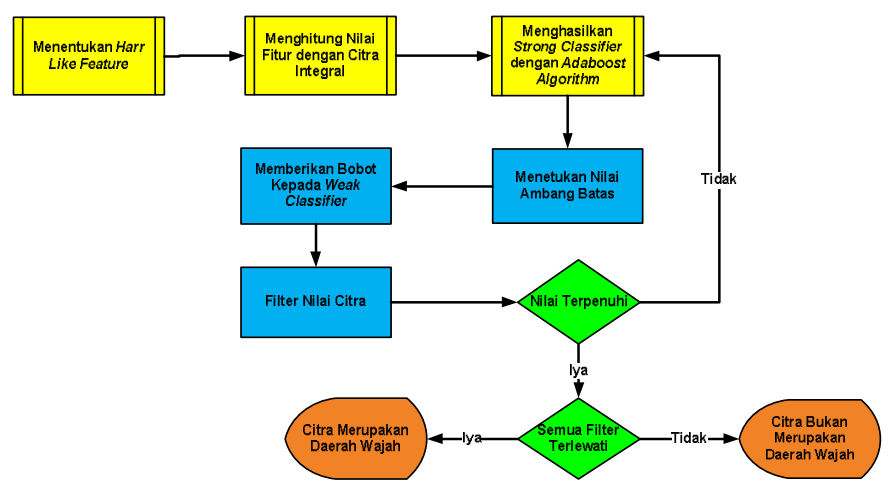

Gambar 1 : Flowchart Algoritma Viola-Jones

\section{B. Gambaran Umum}

Sistem monitoring kehadiran perkuliahan menggunakan face detection merupakan suatu penelitian yang melakukan eksperimen terhadap kelemahan-kelemahan pada saat melakukan presensi di ruangan kelas, kelemahan-kelemahan yang dimaksud adalah pada saat melakukan presensi terdapat sebagian mahasiswa yang melakukan duplikasi tanda tangan atau titip absen, pemantauan kehadiran yang masih manual dengan mengecek setiap presensi perkuliahan, dan terdapat sebagian mahasiswa yang kuliah tidak sesuai dengan jadwal perkuliahan. Hasil penelitian ini diharapkan mampu menyelesaikan masalah-masalah yang dihadapi oleh bagian akademik. Adapun tahapan proses yang akan dilakukan pada penelitian ini akan lebih rinci dapat dilihat pada Gambar 2. 


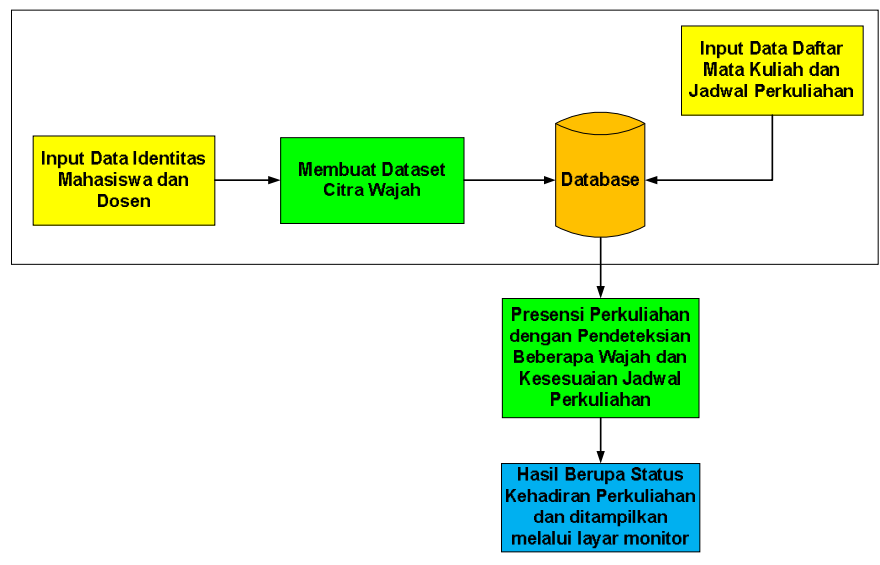

Gambar 2: Blok Diagram Penelitian

Dapat dilihat pada Gambar 2 proses pertama yang dilakukan pada penelitian ini adalah menginput data identitas mahasiswa, membuat dataset citra wajah, menginput data jadwal perkuliahan dan jadwal perkuliahan ke sistem. Setelah proses tahapan pendeteksian wajah, tahap selanjutnya adalah proses pengenalan wajah ketika melakukan presensi perkuliahan yang sudah disinkronisasi oleh jadwal perkuliahan.

\section{Rancangan Presensi Perkuliahan}

Pada tahap ini merupakan tahapan-tahapan yang akan dilalui oleh sistem monitoring kehadiran perkuliahan berbasis face detection menggunakan algoritma Viola-Jones pada saat melakukan presensi. Tahapan-tahapan pada proses presensi perkuliahan disajikan pada Gambar 3.

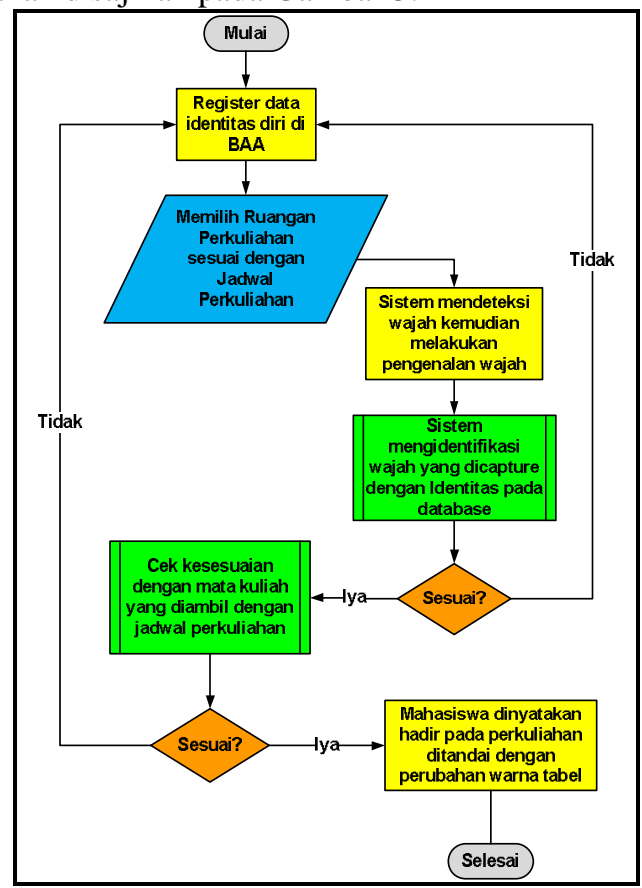

Gambar 3 : Diagram Alur Presensi Perkuliahan

D. Proses Pengenalan Wajah

Pada proses pengenalan wajah, data-data citra wajah terlebih dahulu mengalami proses ekstraksi ciri sehingga citracitra tersebut memiliki suatu nilai karakteristik. Nilai karakteristik tersebut akan disimpan ke dalam basis data sehingga membentuk suatu dataset citra wajah. Kemudian

Zulfachmi: Sistem Monitoring Kehadiran Perkuliahan ... dataset citra tersebut akan diklasifikan dengan citra masukan sebagai data uji untuk mendapatkan hasil pengenalan suatu citra dengan menggunakan metode KNN. Proses pengenalan wajah disajikan pada Gambar 4.

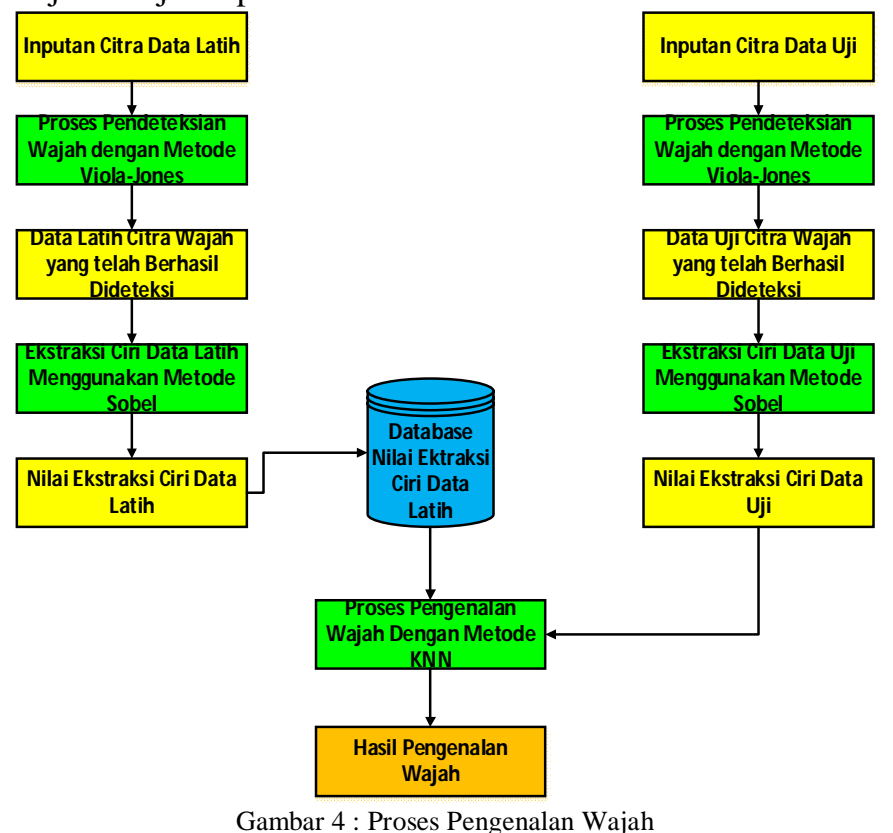

III. HASIL DAN PEMBAHASAN

\section{A. Proses Pengambilan Dataset Citra Wajah}

Pada tahap ini proses pendeteksian wajah dilakukan untuk mengambil dataset citra wajah dari masing-masing mahasiswa kemudian disimpan ke dalam sistem. Data citra wajah yang disimpan pada tahap ini nantinya akan digunakan sebagai data latih untuk proses presensi. Alur proses pendeteksian wajah pada sistem monitoring kehadiran perkuliahan disajikan pada Gambar 5.

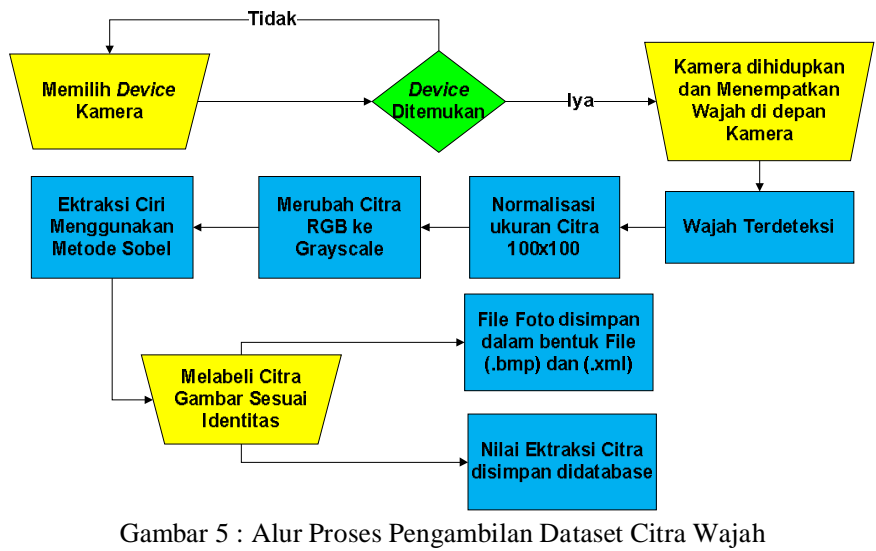

Penelitian ini menggunakan kamera B-Pro 5 dengan resolusi $1280 \times 720$ piksel untuk proses pendeteksian wajah. Kamera berfungsi untuk mengcapture wajah apabila wajah telah terdeteksi. Setelah wajah berhasil dideteksi maka citra wajah akan terlebih dahulu dirubah ukurannya menjadi 100x100 piksel. Langkah selanjutnya ialah merubah citra wajah dari format RGB (Red, Green, Blue) ke Grayscale. Setelah citra grayscale didapati maka dilakukan proses preprocessing untuk mendeteksi tepi suatu citra dengan menggunakan metode Sobel. Preprocessing berguna untuk p-ISSN:1693 - 2951; e-ISSN: 2503-2372 
mendapatkan nilai dari suatu citra kemudian nilai citra tersebut akan disimpan ke database. Nilai-nilai tersebut nantinya akan menjadi nilai pembanding disaat proses presensi. File-file foto akan tersimpan ke dalam bentuk bitmap (.bmp) dan nama file akan tersimpan dalam bentuk file (.xml). Proses pendeteksian wajah pada sistem dapat dilihat pada Gambar 6.

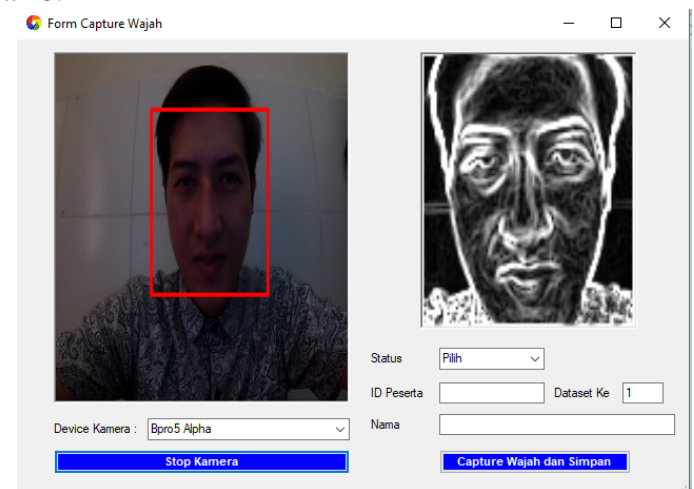

Gambar 6 : Form antarmuka Pengambilan Dataset Citra Wajah

\section{B. Hasil Analisa Pendeteksian Wajah}

Pada penelitian ini wajah akan dideteksi secara sempurna apabila wajah dihadapkan secara tegak lurus menghadap ke kamera. Selain itu, terdapat beberapa posisi wajah yang dapat dideteksi oleh sistem monitoring kehadiran perkuliahan ini. Posisi wajah yang dapat dideteksi oleh sistem dapat disajikan pada Tabel I.

TABEL I

POSISI WAJAH YANG TERDETEKSI

\begin{tabular}{|l|l|c|l|}
\hline Posisi Wajah & Keterangan & Posisi Wajah & Keterangan \\
\hline & $\begin{array}{l}\text { Posisi wajah } \\
\text { tegak lurus ke } \\
\text { arah kamera }\end{array}$ & $\begin{array}{l}\text { Posisi wajah } \\
\text { menoleh sebelah } \\
\text { kanan }\end{array}$ \\
\hline & $\begin{array}{l}\text { Posisi wajah } \\
\text { menoleh sebelah } \\
\text { kiri }\end{array}$ & & $\begin{array}{l}\text { Posisi wajah } \\
\text { menggunakan } \\
\text { kacamata }\end{array}$ \\
\hline & $\begin{array}{l}\text { Posisi wajah } \\
\text { menjauhi kamera }\end{array}$ & $\begin{array}{l}\text { Posisi wajah } \\
\text { mendekati kamera }\end{array}$ \\
\hline & $\begin{array}{l}\text { Posisi wajah } \\
\text { dengan ekspresi } \\
\text { senyum }\end{array}$ & $\begin{array}{l}\text { Posisi hidung dan } \\
\text { mulut ditutupi } \\
\text { oleh tangan }\end{array}$ & $\begin{array}{l}\text { Posisi wajah } \\
\text { mengadah ke atas }\end{array}$ \\
\hline
\end{tabular}

Berdasarkan Tabel I terdapat 10 kriteria posisi wajah yang dapat dideteksi oleh sistem monitoring kehadiran perkuliahan ini. Selain itu terdapat juga posisi wajah yang tidak dapat dideteksi oleh sistem. Posisi wajah yang tidak terdeteksi dapat dilihat pada Tabel II.

TABEL II

POSISI WAJAH YANG TIDAK TERDETEKSI

\begin{tabular}{|c|l|c|l|}
\hline Posisi Wajah & \multicolumn{1}{|c|}{ Keterangan } & Posisi Wajah & \multicolumn{1}{|c|}{ Keterangan } \\
\hline & $\begin{array}{l}\text { Posisi wajah } \\
\text { merunduk ke } \\
\text { bawah }\end{array}$ & $\begin{array}{l}\text { Posisi wajah miring } \\
\text { ke kiri }\end{array}$ \\
\hline & $\begin{array}{l}\text { Posisi wajah } \\
\text { miring ke kanan }\end{array}$ & & $\begin{array}{l}\text { Posisi wajah hanya } \\
\text { setengah frame }\end{array}$ \\
\hline & $\begin{array}{l}\text { Posisi wajah } \\
\text { dengan dahi tidak } \\
\text { kelihatan }\end{array}$ & & $\begin{array}{l}\text { Posisi wajah } \\
\text { ditutupi oleh tangan } \\
\text { setengah wajah }\end{array}$ \\
\hline
\end{tabular}

C. Dataset Citra Wajah

Pada Penelitian ini terdapat 10 jumlah mahasiswa yang digunakan sebagai objek penelitian. Dari masing-masing data tersebut akan diambil citra wajah yang digunakan sebagai data latih citra, dimana data latih citra yang diambil sebanyak 10 data latih citra. Untuk rincian data latih citra dapat dilihat pada Tabel III.

TABEL III

DATASET CITRA LATIH MAHASISWA

\begin{tabular}{|c|c|c|c|c|c|c|c|c|c|c|c|c|}
\hline \multicolumn{13}{|c|}{ Dataset Citra Wajah } \\
\hline No & NIM & Nama & 1 & 2 & 3 & 4 & (a) & & 7 & 8 & 9 & 10 \\
\hline 1 & 1216001 & Amin Budi Utomo & 60 & 69 & 60 & (69) & (2) & (6) & 60 & & 69 & $b$ \\
\hline 2 & 1216002 & Teodorus Lende & 25 & 25 & 25 & 85 & 25 & 25 & 25 & at. & (5) & \\
\hline 3 & 1216003 & Maria Koni Milla & & & & & & & & & & \\
\hline 4 & 1216004 & Natalia Geli & & & & & & 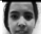 & & & & \\
\hline 5 & 1216005 & I Gusti Lanang Pria Utama & & & & & & (20) $>0$ & & & & \\
\hline 6 & 1216007 & Yohanes Budiman & & & & & & & & & & \\
\hline 7 & 1216008 & Petrus Rafael Dhae & & & & $(29$ & & 85 & & & & \\
\hline 8 & 1216011 & Frengki F. Maukaling & & & & & & & & & & \\
\hline 9 & 1216013 & Apriyones Zaid & & & & & & & & & & \\
\hline 10 & 1216014 & Agustinus Bulu & & & & & & & & & $\Rightarrow$ & \\
\hline
\end{tabular}

\section{Pengenalan Wajah}

Pada tahap ini, pengenalan wajah dilakukan untuk mengetahui identitas diri seseorang pada saat melakukan presensi. Proses pengenalan wajah dapat dilakukan setelah dataset data citra latih wajah terdaftar pada sistem monitoring kehadiran perkuliahan. Pada penelitian ini sistem akan mengecek terlebih dahulu apakah mahasiswa tersebut benar mengambil mata kuliah tersebut atau tidak. Jika mata kuliah tersebut benar diambil oleh peserta perkuliahan maka data presensi akan tersimpan ke dalam database dan ditandai dengan perubahan warna pada kolom tabel absen peserta perkuliahan. Proses presensi kehadiran berbasis pengenalan wajah dapat dilihat pada Gambar 7. 


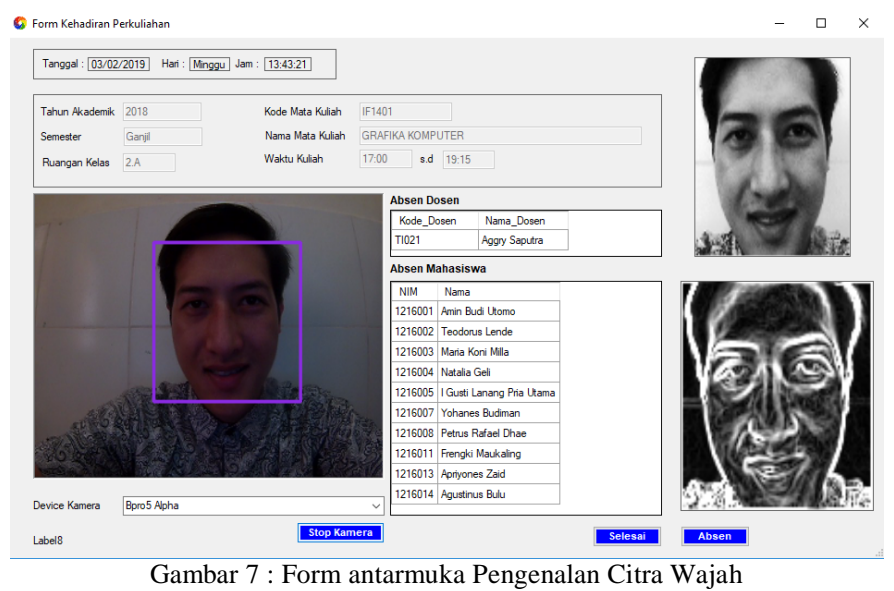

Berdasarkan pada Gambar 7 apabila mahasiswa telah berhasil melakukan presensi maka kolom pada tabel absen pengenalan wajah peserta perkuliahan akan berubah warna menjadi warna hijau.

\section{E. Hasil Pengujian Pengenalan Citra Wajah}

Hasil dari keseluruhan pengujian sistem pengenalan wajah yang dilakukan terhadap mahasiswa STMIK Bandung Bali disajikan pada Tabel IV.

TABEL IV

DATASET CITRA LATIH MAHASISWA

\begin{tabular}{|c|c|l|c|c|c|}
\hline No & NIM & \multicolumn{1}{|c|}{ Nama } & $\begin{array}{c}\text { Total } \\
\text { Pengujian }\end{array}$ & $\begin{array}{c}\text { Berhasil } \\
\text { Dikenali }\end{array}$ & $\begin{array}{c}\text { Dikenali } \\
\text { Sebagai } \\
\text { Mahasiswa Lain }\end{array}$ \\
\hline 1 & 1216001 & Amin Budi Utomo & 36 & 36 & 0 \\
\hline 2 & 1216002 & Teodorus Lende & 33 & 33 & 0 \\
\hline 3 & 1216003 & Maria Koni Mila & 38 & 36 & 2 \\
\hline 4 & 1216004 & Natalia Geli & 39 & 39 & 0 \\
\hline 5 & 1216005 & I.G. Lanang P.Utama & 36 & 34 & 2 \\
\hline 6 & 1216007 & Yohanes Budiman & 34 & 31 & 3 \\
\hline 7 & 1216008 & Petrus Rafael Dhae & 38 & 37 & 1 \\
\hline 8 & 1216011 & Frengki Maukaling & 37 & 32 & 5 \\
\hline 9 & 1216013 & Aprivones Zaid & 38 & 37 & 1 \\
\hline 10 & 1216014 & Agustinus Bulu & 36 & 31 & 5 \\
\hline
\end{tabular}

Berdasarkan Tabel IV telah dilakukan pengujian citra wajah sebanyak 365 data pada 10 mahasiswa dengan menggunakan 100 dataset citra wajah. Dimana dalam pengujian tersebut terdapat beberapa mahasiswa yang pengenalan citra wajahnya yang tidak sesuai dengan identitas aslinya atau terjadi kemiripan dengan mahasiswa lainnya

\section{F. Pengujian Pengenalan Citra Wajah yang tidak sesuai}

Pada penelitian ini selain citra wajah dapat dikenali sesuai identitas aslinya terdapat juga beberapa citra wajah yang dikenali sebagai mahasiswa lain oleh sistem. Adapun hasil pengenalan wajah yang dikenali sebagai mahasiswa lain atau tidak sesuai dengan identitas aslinya disajikan pada Gambar 8.
Hasil Pengenalan Citra Wajah yang Tidak Sesuai

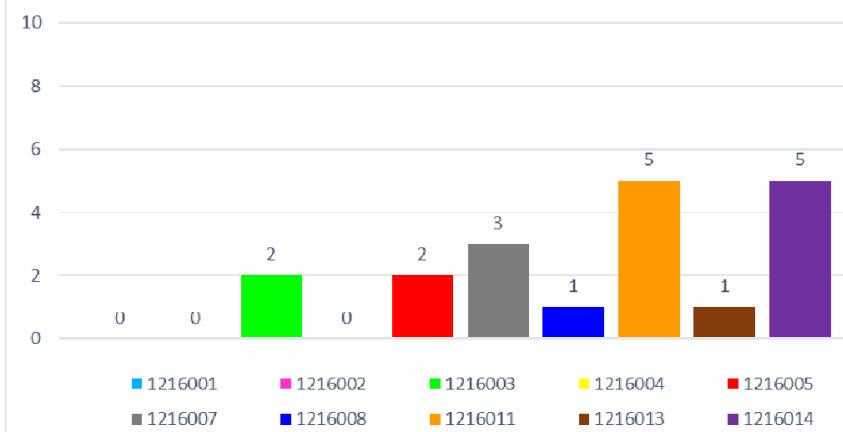

Gambar 8 : Grafik Hasil Pengenalan Citra yang tidak sesuai

Berdasarkan Gambar 8 citra wajah yang tidak sesuai identitas aslinya paling banyak terjadi pada mahasiswa dengan NIM 1216014 dan 1216011 yaitu masing-masingnya sebanyak 5 data, kemudian mahasiswa dengan NIM 1216007 sebanyak 3 data, mahasiswa dengan NIM 1216003 dan 1216005 sebanyak 2 data, serta mahasiswa dengan NIM 1216008 dan 1216013 sebanyak 1 data.

\section{G. Hasil Metode KNN terhadap citra yang tidak sesuai}

Pada penelitian ini metode KNN digunakan sebagai metode klasifikasi untuk pengenalan wajah. Adapun implementasi metode KNN dari penelitian ini yaitu untuk mencari nilai terdekat dari nilai citra wajah pada saat presensi dengan nilai citra wajah pada dataset. Pada penelitian ini menggunakan nilai $\mathrm{k}=5$ untuk mencari nilai dari tetangga terdekat. Pada tahap ini menyajikan hasil klasifikasi metode KNN terhadap hasil yang wajah pada saat presensi dikenali sebagai mahasiswa lain atau tidak sesuai identitas aslinya. Adapun hasil citra yang tidak sesuai identitas aslinya menggunakan metode KNN disajikan pada Tabel V.

TABEL $\mathrm{V}$

\begin{tabular}{|c|c|c|c|c|c|}
\hline No & $\begin{array}{c}\text { Citra } \\
\text { Inputan }\end{array}$ & $\begin{array}{l}\text { Output } \\
\text { Aktual }\end{array}$ & $\begin{array}{l}\text { Output } \\
\text { Sistem }\end{array}$ & Jarak KNN $(k=5)$ & Label \\
\hline 1 & & 1216014 & 1216011 & $\begin{array}{ll}\text { 1) } & 11678.361486099 \\
\text { 2) } & 12368.1938859318 \\
\text { 3) } & 12729.3065797002 \\
\text { 4) } 13319.9386259847 \\
\text { 5) } 13351.451494126\end{array}$ & $\begin{array}{ll}\text { 1) } & 1216014 \\
\text { 2) } & 1216011 \\
\text { 3) } 1216011 \\
\text { 4) } 1216004 \\
\text { 5) } 1216004\end{array}$ \\
\hline 2 & & 1216014 & 1216007 & $\begin{array}{ll}\text { 1) } & 13206.7659932324 \\
\text { 2) } & 13316.5867623802 \\
\text { 3) } & 13343.8567887999 \\
\text { 4) } & 13513.6071424324 \\
\text { 5) } & 13521.6260486674\end{array}$ & $\begin{array}{ll}\text { 1) } & 1216007 \\
\text { 2) } & 1216007 \\
\text { 3) } & 1216001 \\
\text { 4) } 1216007 \\
\text { 5) } 1216001\end{array}$ \\
\hline 3 & & 1216014 & 1216001 & $\begin{array}{ll}\text { 1) } & 8993.19592803359 \\
\text { 2) } & 10129.2713459557 \\
\text { 3) } & 10214.2583186446 \\
\text { 4) } 10251.3827847759 \\
\text { 5) } 10290.3400818437\end{array}$ & $\begin{array}{ll}\text { 1) } & 1216014 \\
\text { 2) } & 1216001 \\
\text { 3) } 1216001 \\
\text { 4) } 1216001 \\
\text { 5) } 1216001\end{array}$ \\
\hline 4 & & 1216011 & 1216003 & $\begin{array}{ll}\text { 1) } & 9164.52382832845 \\
\text { 2) } & 11012.1438875452 \\
\text { 3) } & 11015.4963574049 \\
\text { 4) } & 11043.5170122566 \\
\text { 5) } & 11111.6490225349\end{array}$ & $\begin{array}{l}\text { 1) } 1216011 \\
\text { 2) } 1216003 \\
\text { 3) } 1216003 \\
\text { 4) } 1216003 \\
\text { 5) } 1216003\end{array}$ \\
\hline 5 & & 1216011 & 1216003 & $\begin{array}{ll}\text { 1) } & 10787.0991930176 \\
\text { 2) } & 10876.9261742461 \\
\text { 3) } & 10929.4361245217 \\
\text { 4) } & 10930.9112611895 \\
\text { 5) } & 10953.5319417985\end{array}$ & $\begin{array}{ll}\text { 1) } 1216003 \\
\text { 2) } 1216003 \\
\text { 3) } 1216003 \\
\text { 4) } 1216003 \\
\text { 5) } 1216003\end{array}$ \\
\hline
\end{tabular}

Berdasarkan Tabel V terdapat beberapa citra wajah dengan hasil pengenalannya dikenali sebagai mahasiswa lain, hal tersebut terjadi karena klasifikasi keanggotaan dari label mahasiswa yang identitasnya tidak sesuai lebih banyak

p-ISSN:1693 - 2951; e-ISSN: 2503-2372 
daripada label identitas aslinya sehingga hasil pengenalan citra menjadi bukan identitas aslinya.

\section{H. Hasil Pengujian Jarak dan Posisi Wajah}

Pada penelitian ini jarak dan posisi wajah pada saat proses pengambilan citra wajah akan menentukan tingkat akurasi dari pengenalan wajah. Pengujian ini dilakukan terhadap mahasiswa yang mengalami permasalahan paling banyak dalam proses pengenalan wajah sebelumnya. Pengujian jarak dan posisi wajah disajikan pada Tabel VI.

TABEL VI

\begin{tabular}{|c|c|c|c|c|c|c|c|}
\hline $\begin{array}{c}\text { Citra } \\
\text { Inputan }\end{array}$ & Posisi & $\begin{array}{c}\text { Jarak } \\
(\mathrm{cm})\end{array}$ & Status & $\begin{array}{c}\text { Citra } \\
\text { Inputan }\end{array}$ & Posisi & $\begin{array}{c}\text { Jarak } \\
(\mathrm{cm})\end{array}$ & Status \\
\hline & $\begin{array}{l}\text { Tegak lurus } \\
\text { menghadap } \\
\text { ke depan }\end{array}$ & 40 & Dikenali & & $\begin{array}{l}\text { Tegak lurus } \\
\text { menghadap } \\
\text { ke depan }\end{array}$ & 20 & Dikenali \\
\hline & $\begin{array}{l}\text { Menoleh ke } \\
\text { kanan }\end{array}$ & 40 & 1216003 & & $\begin{array}{l}\text { Menoleh ke } \\
\text { kanan }\end{array}$ & 20 & 1216008 \\
\hline & $\begin{array}{l}\text { Menoleh ke } \\
\text { kiri }\end{array}$ & 40 & Dikenali & & $\begin{array}{l}\text { Menoleh ke } \\
\text { kiri }\end{array}$ & 20 & 1216003 \\
\hline & $\begin{array}{l}\text { Tegak lurus } \\
\text { menghadap } \\
\text { ke depan }\end{array}$ & 30 & Dikenali & & $\begin{array}{l}\text { Tegak lurus } \\
\text { menghadap } \\
\text { ke depan }\end{array}$ & 10 & 1216003 \\
\hline & $\begin{array}{l}\text { Menoleh ke } \\
\text { kanan }\end{array}$ & 30 & 1216008 & & $\begin{array}{l}\text { Menoleh ke } \\
\text { kanan }\end{array}$ & 10 & 1216003 \\
\hline 4 & $\begin{array}{l}\text { Menoleh ke } \\
\text { kiri }\end{array}$ & 30 & Dikenali & & $\begin{array}{l}\text { Menoleh ke } \\
\text { kiri }\end{array}$ & 10 & 1216008 \\
\hline
\end{tabular}

Berdasarkan Tabel VI metode KNN dapat bekerja dengan baik dalam proses pengenalan wajah dengan jarak minimal $20 \mathrm{~cm}$ dari posisi letak kamera dan posisi wajah dengan menghadap lurus ke depan kamera. Sedangkan pada jarak $10 \mathrm{~cm}$, metode KNN tidak dapat bekerja dengan baik dalam proses pengenalan wajah.

\section{Hasil Perbandingan Pengujian Pengenalan Wajah}

Pada penelitian ini setelah dilakukan proses penentuan jarak dan posisi wajah maka terdapat perbandingan hasil antara pengenalan citra wajah menggunakan penentuan jarak dan posisi wajah dengan pengenalan citra wajah tanpa penentuan jarak dan posisi wajah. Hasil perbandingan pengenalan citra wajah disajikan pada Tabel VII.

TABEL VII

\begin{tabular}{|c|c|c|c|c|c|}
\hline \multirow[b]{2}{*}{ NIM } & \multirow[b]{2}{*}{ Nama } & \multicolumn{2}{|c|}{$\begin{array}{c}\text { Hasil Pengujian Tanpa } \\
\text { Penentuan Jarak dan Posisi } \\
\text { Wajah }\end{array}$} & \multicolumn{2}{|c|}{$\begin{array}{c}\text { Hasil Pengujian dengan } \\
\text { Penentuan Jarak dan Posisi } \\
\text { Wajah }\end{array}$} \\
\hline & & $\begin{array}{l}\text { Berhasil } \\
\text { Dikenali }\end{array}$ & $\begin{array}{l}\text { Dikenali } \\
\text { Sebagai } \\
\text { Mahasiswa } \\
\text { Lain }\end{array}$ & $\begin{array}{l}\text { Berhasil } \\
\text { Dikenali }\end{array}$ & $\begin{array}{l}\text { Dikenali } \\
\text { Sebagai } \\
\text { Mahasiswa } \\
\text { Lain }\end{array}$ \\
\hline 1216001 & Amin Budi Utomo & 36 & 0 & 36 & 0 \\
\hline 1216002 & Teodorus Lende & 33 & 0 & 33 & 0 \\
\hline 1216003 & Maria Koni Mila & 36 & 2 & 38 & 0 \\
\hline 1216004 & Natalia Geli & 39 & 0 & 39 & 0 \\
\hline 1216005 & I.G. Lanang P.Utama & 34 & 2 & 36 & 0 \\
\hline 1216007 & Yohanes Budiman & 31 & 3 & 34 & 0 \\
\hline 1216008 & Petrus Rafael Dhae & 37 & 1 & 38 & 0 \\
\hline 1216011 & Frengki Maukaling & 32 & 5 & 36 & 1 \\
\hline 1216013 & Aprivones Zaid & 37 & 1 & 38 & 0 \\
\hline 1216014 & Agustinus Bulu & 31 & 5 & 36 & 0 \\
\hline 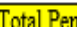 & & 346 & 19 & 364 & \\
\hline
\end{tabular}

\section{Grafik Perbandingan Hasil Pengujian} Pengenalan Citra Wajah

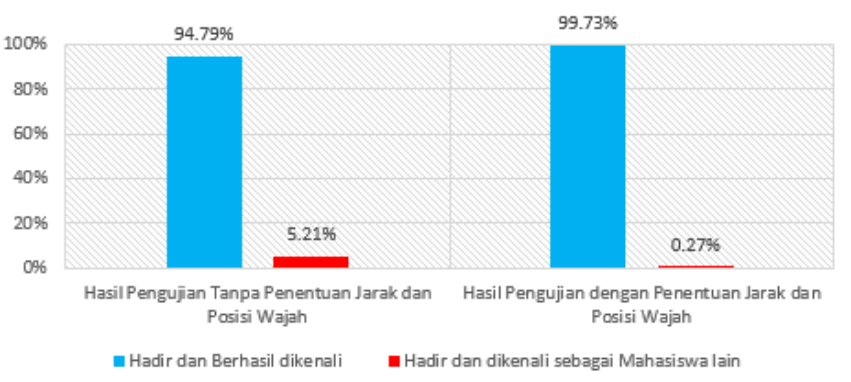

Gambar 9 : Grafik Perbandingan Hasil Pengujian Pengenalan Citra Wajah

Berdasarkan Gambar 9 terdapat perbandingan hasil pengujian pengenalan wajah dimana hasil pengujian pengenalan wajah tanpa penentuan jarak dan posisi wajah menghasilkan tingkat akurasi sebesar 94.79\%. Sedangkan hasil pengujian pengenalan wajah dengan menggunakan penentuan jarak wajah dari kamera dan posisi wajah terjadi peningkatan tingkat akurasi menjadi $99.73 \%$.

\section{KESIMPULAN}

Berdasarkan penelitian yang telah dilakukan dapat disimpulkan:

1. Sistem monitoring kehadiran perkuliahan berbasis pendeteksian wajah berhasil dikombinasikan dengan jadwal perkuliahan dan daftar mata kuliah yang diambil oleh mahasiswa.

2. Algoritma Viola Jones berhasil diterapkan pada proses pendeteksian wajah di sistem monitoring kehadiran perkuliahan.

3. Metode KNN pada proses pengenalan wajah bekerja dengan baik pada jarak minimal $20 \mathrm{~cm}$ dari posisi kamera dan posisi wajah tegak lurus.

4. Hasil penelitian menunjukan bahwa terjadi peningkatan tingkat akurasi pengenalan citra wajah antara menggunakan penentuan jarak dan posisi wajah dengan tidak menggunakan penentuan jarak dan posisi wajah.

5. Hasil akurasi menggunakan penentuan jarak dan posisi wajah menghasilkan akurasi sebesar $99.73 \%$, sedangkan tanpa menggunakan penentuan jarak dan posisi wajah menghasilkan akurasi sebesar $94.79 \%$

\section{REFERENSI}

[1] N. Dhanalakshmi, S. G. Kumar, and Y. P. Sai, "Aadhaar based biometric attendance system using wireless fingerprint terminals," Proc. - 7th IEEE Int. Adv. Comput. Conf. IACC 2017, pp. 651-655, 2017.

[2] P. S. S. Srivignessh and M. Bhaskar, "RFID and pose invariant face verification based automated classroom attendance system," Int. Conf. Microelectron. Comput. Commun. MicroCom 2016, 2016.

[3] M. Sajid et al., "Automated Attendance System using Machine Learning Approach,” Int. J. Adv. Res. Comput. Commun. Eng., vol. 3, no. 1, pp. 501-505, 2017.

[4] N. K. Jayant and S. Borra, "Attendance Management System Using Hybrid Face Recognition Techniques," 2016 Conf. Adv. Signal Process., pp. 412-417, 2016.

[5] D. P. S. Mangayarkarasi Nehru, "Illumination invariant face detection," Int. Conf. Adv. Comput. Commun. Syst. (ICACCS -2017), vol. Jan. 06-07, pp. 4-7, 2017.

[6] P. B. S. Dodit Suprianto, Rini Nur Hasanah, "Sistem Pengenalan Wajah Secara Real-Time dengan Adaboost, Eigenface PCA \& MySQL," $J$. EECCIS (Electrics, Electron. Commun. Control. Informatics, Syst., vol. 7 , 
no. 2, pp. 179-184, 2013

[7] C. Suhery and I. Ruslianto, "Identifikasi Wajah Manusia untuk Sistem Monitoring Kehadiran Perkuliahan menggunakan Ekstraksi Fitur Principal Component Analysis ( PCA )," J. Edukasi dan Penelit. Inform., vol. 3, no. 1, pp. 9-15, 2017.

[8] B. S. M. Zufar, "Convolutional Neural Networks untuk Pengenalan Wajah Secara Real - Time," J. SAINS dan SENI ITS, vol. 5, no. 2, pp. 7277, 2016.

[9] P. S. Chandak, M. Patange, H. Deshpande, S. Maredia, and P. Bagwe, "A Prototype of Automated Attendance System Using Image Processing," Int. J. Adv. Res. Comput. Commun. Eng., vol. 5, no. 4, pp. 501-505, 2016.

[10]E. Rekha and P. Ramaprasad, "An efficient automated attendance management system based on Eigen Face recognition," Proc. 7th Int. Conf. Conflu. 2017 Cloud Comput. Data Sci. Eng., vol. 5, pp. 605-608, 2017.

[11] A. Hendrotriatmoko, S. Hadi, and H. S. Dachlan, "Penggunaan Metode Viola-Jones dan Algoritma Eigen Eyes dalam Sistem Kehadiran Pegawai," J. EECCIS, vol. 8, no. 1, pp. 41-46, 2014.

[12]J. Efendi, M. I. Zul, and W. Yunanto, "Real Time Face Recognition using Eigenface and Viola-Jones Face Detector," Int. J. Informatics Vis., vol. 1, no. 1, pp. 16-22, 2017.

[13]D. Indra, "Pendeteksian tepi objek menggunakan metode gradien," J. Ilm. Ilk., vol. 8, no. Agustus, pp. 69-75, 2016.

[14]T. Y. Prahudaya and A. Harjoko, "Metode Klasifikasi Mutu Jambu Biji Menggunakan Knn Berdasarkan Fitur Warna Dan Tekstur," $J$ Teknosains, vol. 6, no. 2, p. 113, 2017 
[Halaman ini sengaja di kosongkan] 